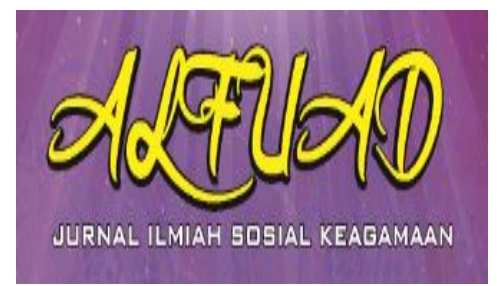

ALFUAD JOURNAL, 5 (1), 2021,(24-29)

(E-ISSN 2714-7606 P-ISSN 2614-4786 )

Available online at

http://ecampus.iainbatusangkar.ac.id/ojs/index.php/alfuad

\title{
Community Perspective on The Activities of The Sholawat Assembly During Pandemic
}

\author{
Nanda Tri Ikfinil Wulandari*) \\ Universitas Negeri Surabaya \\ Indonesia \\ E-mail: nanda.18013@mhs.unesa.ac.id
}

\section{Agus Machfud Fauzi}

Universitas Negeri Surabaya, Indonesia

E-mail: agusmfauzi@unesa.ac.id

*) Corresponding Author

\begin{abstract}
During the pandemic, restrictions on various activities were prohibited by the government and WHO. The community can still carry out activities with social restrictions. However, religious activities still carry out restrictions. However, in the religious community they carry out according to government recommendations. One of the activities that do not escape the characteristics of Muslims is the presence of prayer assemblies. Sholawat assemblies are activities carried out by groups of people who have such great love for the Prophet and God. The purpose of this study was to determine the views of the Anggaswangi village community, especially the mosque youth on the activities of prayer assemblies during the pandemic. The method used is a qualitative research method, because researchers need to approach in depth with the Anggaswangi village community in order to get data directly from informants. The theory used is Max Weber's theory of social behavior. This theory explains that according to Weber, the individual human being in society is a creative actor and social reality is not a static tool rather than the coercion of social facts. That is, human action is not fully determined by the norms, habits, values, etc. which are included in the concept of social facts. The initial assumption in this study is that the people of Anggaswangi village view religious activities as a form of love for God, but activities such as Majeliis Sholawat can also be used as activities to pray to God because of the situation during the Covid-19 pandemic.
\end{abstract}

Keywords: Pandemic, Prayer Council, Community

\section{INTRODUCTION}

In 2020 has spread a very dangerous virus, which can attack the respiratory system in humans. The virus, known as the corona virus (Covid-19), spread in Indonesia in March 2020. Since then, the Indonesian government has implemented the Large-Scale Social Restrictions (PSBB) system (source not listed). This was implemented by Indonesian citizens to break the chain of the spread of the corona virus. All activities carried out outside the home, whether working, studying, or worshiping, must be done at home. During the pandemic, restrictions on various activities are prohibited by the government and WHO. The restrictions begin for 14 days 
until the rate of the spread of the corona virus decreases. However, in Indonesia the virus continues to grow and increase so that the period of large-scale social restrictions is added to 14 days.

Indonesia has used the PSBB system which has threatened the community's economy. People's incomes began to decline. The majority of people experience layoffs, they survive in a vacuum of productive activities. On the other hand, religious activities are also quite difficult to carry out. It is undeniable that Indonesian society is a religious society bound by collective religious rites, for example praying in congregation in the community. Therefore, it is undeniable that there are still some community groups who continue to carry out religious rituals in congregation.

Recently, in the New Normal era, the people of the village of Anggaswangi have carried out religious activities that caused people to gather in one place. Anggaswangi Village is one of the villages where the majority of the population is NU Muslim. In NU Islam, it is taught to fear God and the Prophet Muhammad. As a form of love for the Prophet, Muslims perform prayers together by mentioning the names of Allah and the Prophet. This religious activity is usually followed by a community of prayer lovers.
Previous research shows that the government's prohibition on cessation and restrictions on religious and educational activities during the Covid-19 pandemic, such as: restrictions on religious and educational activities that are carried out face-to-face, are things that are allowed in the Shari'a for the benefit of humans. It is permissible for Muslims not to carry out religious and educational activities during the existence and spread of the epidemic, such as taklim and lectures as well as faceto-face learning and replacing them with online methods, or the use of online-based digital media.

In further research, it shows the fact that religious activities carried out by religious communities during the Covid-19 pandemic have changed. At the surface level, Muslim worship, which was originally frenetic and open in public spaces, currently tends to be quiet and closed. Community participation in Friday prayers and Eid prayers is very high, so it encourages them to do it in congregation regardless of the risk. Meanwhile, religious activities that can be done alone tend to be low, because they can do it at home. They continue to carry out activities outside their homes while still practicing social distancing and implementing health protocols. The novelty of this research is to find out the views of the Anggaswangi village community regarding the religious 
activities that they continue to carry out despite the pandemic situation with all its risks.

\section{METHOD}

This study uses qualitative research methods with the perspective of social behavior theory by Max Weber. The basic assumption of the theory of social behavior according to Weber, human individuals in society are creative actors and social reality is not a static tool rather than a coercion of social facts. That is, human actions are not fully determined by the norms, habits, values, and so on which are included in the concept of social facts. Weber also introduced the concept of a verstehen approach to understand the meaning of one's actions, assuming that a person in acting does not only carry out it but also places himself in the environment of thinking and behavior of others.

Every individual or even a group must interact with each other. Social interaction is a behavior that can be categorized as a social action. Social action is the process of actors involved in making subjective decisions about the means and ways to achieve certain goals that have been chosen, these actions regarding all types of human behavior, aimed at others, past, present and expected in the future. will come. Social action according to Weber is an individual action as long as the action has a subjective meaning or meaning for him and is directed to the actions of others. Weber distinguishes human social action into four types: Instrumental Rationality Actions, Value Rational Actions, Affective Actions, Traditional Actions.

According to Weber, social behavior is also rooted in individual consciousness and starts from there. Individual behavior is a unit of sociological analysis, even family, state, party, etc. Weber argues that the study of social life which studies social institutions and structures from the outside, as if there is no inside-story, and therefore excludes self-direction by individuals, does not reach the main and essential elements of social life.

Data collection techniques in this study were carried out by making primary data and secondary data as data sources. In primary data, the researcher uses the results of interviews conducted with several mosque youths and the people of the village of Angaswangi. While secondary data is data obtained indirectly, the data can be obtained from books, journals, news and some previous research that has to do with the community's perspective on the activities of the prayer assembly during the pandemic. The subjects of this study were the people of the village of Anggaswangi and the youth 
of the mosque of the village of Anggaswangi.

Data analysis technique in this research is descriptive analysis technique. Data technique with perspective is a way of examining an object, the state of the system of thought at this time. With this descriptive qualitative research method, it can be used to explain social phenomena at certain times.

\section{RESULT AND DISCUSSION}

From the results of observations and interviews with several administrators of the Baitul Ubaidillah mosque, Anggaswangi village, Sukodono district, that they do not carry out religious activities every day. So that the community and youth of the mosque have a routine schedule of activities. They have some religious activities involving the masses. The activities they have detailed are carried out once a week and once a month. The activities they mean are sholawat assembly events and diba events. This event is not only their main activity, there are several other activities such as the commemoration of Islamic holidays. The commemoration of this great Islamic achievement, the youth of the mosque was never absent with events to enliven the Anggaswangi village mosque.

If in a pandemic situation like this, the number of people infected with the
Covid-19 virus continues to increase in Indonesia. The government has warned that the New Normal era has been running for several months. However, the government has appealed to the people of Indonesia to keep their distance, wear masks when traveling, and wash their hands after traveling. However, apart from this, the government also urges residents who hold activities that cause crowds or involve large numbers of people, it is recommended that a minimum of $50 \%$ of the people's capacity be held. In addition, for employees and office workers, it is recommended that the company provide a similar policy. $50 \%$ of employees work in offices and the rest work from home. Because this is an effort to prevent the spread of the virus in the workplace.

The activities carried out by the youth of the Anggaswangi village mosque are activities that cause crowds and require a short period of time. At least $1 \frac{1}{2}$ hours of activity implementation. According to local residents, the youth of the mosque hold activities as a form of request or ask God for help and forgiveness for the people of Indonesia.

Actions taken by mosque youth are included in social actions in Weber's theory. Every human being performs actions that have meaning and purpose. Therefore, social action runs in a structured manner. Weber's four types of 
social action, the formulation of the problem this time belongs to the type of instrumental rational action. This action is a social action that is carried out by a person based on conscious considerations and choices related to the purpose of the action and the availability of the tools used to achieve it. If analyzed, the actions taken by the youth of the mosque are based on consideration of a fairly difficult situation. The pandemic period is a difficult time to carry out activities outside the home, especially activities that involve many people. Therefore, this activity makes a consideration between fear of virus transmission and to carry out obligations as human beings who fear Allah SWT.

According to some residents who live around the mosque. They were initially a little disturbed by their activities during the pandemic, but some time passed they were supportive. Because religious activities are activities that have positive values, as religious people, of course, they have their own guidelines for obeying God's commands. Islam upholds the ties of friendship and upholds the prophet Muhammad. So, as mosque youth they have a goal to pray together by mentioning the names of Allah and Muhammad for the salvation of the hereafter.

In the observations of the researchers, during the activity, the entire committee and invited guests implemented health protocols such as: wearing masks, washing hands and spraying hand sanitizer, and keeping a distance. Then, they also provide packaged food to avoid unhygienic food due to a lot of touching hands. They carry out activities at night, where their goal is for local residents and invited guests to attend because working hours are over. In addition to the sholawat assembly event that they hold, on other Islamic holidays they always accompany them with sholawat together. Because according to the belief of the Islamic religion, that sholawat is chanted to pray to the Prophet and not to praise Him. Some groups think that sholawat is praising the Prophet but, in fact, as Muslims, especially the NU (Nahdlatul Ulama) sect, sholawat is the same as praying for the Prophet to Allah SWT.

Impact on religious activities: (1) Get the Prophet's intercession for Muslims because as their helper and get a reward. (2) Strengthening the relationship between fellow Muslims and neighbors who are far from home. (3) Add knowledge and new friends. (4) Make yourself more pious to Allah SWT. (4) Make the mind more calm and peaceful because of the readings that have been spoken.

Based on this impact, the local community is more supportive of these religious activities even in a pandemic situation. However, continue to comply 
with health protocols and maintain a healthy body.

\section{CONCLUSION}

It can be concluded that the people of Anggaswangi village consider that religious activities can show a positive nature towards the environment. During the activity, the village community did not feel disturbed and supported the activity. Even during the pandemic, still ask for prayers to God. The actions they take are actions that have clear goals and are based on difficult considerations, especially the pandemic situation. In addition, community participation is quite high because the majority of the population of Anggaswangi village are NU Muslims. So it really supports the religious activities of the sholawat assembly.

The impact that can be seen is making oneself more faithful and changing oneself for the better, maintaining the ties of friendship between fellow human beings, adding religious knowledge and new friends, and getting the intercession of the Prophet.

\section{REFERENCES}

Darmawan, D., Miharja, D., Waluyajati, R. S. R., \& Isnaeniah, E. (2020). Sikap Keberagamaan Masyarakat Menghadapi Wabah COVID-19. Religious: Jurnal Studi AgamaAgama Dan Lintas Budaya, 4(2), 115-124. https://doi.org/10.15575/rjsalb.v4i2
.8596

Muhlis, A., \& Norkholis, N. (2016). ANALISIS TINDAKAN SOSIAL MAX WEBER DALAM TRADISI PEMBACAAN KITAB MUKHTASHAR AL-BUKHARI (Studi Living Hadis). Jurnal Living Hadis.

https://doi.org/10.14421/livinghadis .2016 .1121

Supraja, M. (2015). Alfred Schutz: Rekonstruksi Teori Tindakan Max Weber. Jurnal Pemikiran Sosiologi.

https://doi.org/10.22146/jps.v1i2.23 447

Usman, M. H., Aswar, \& Irawan, A. W. (2020). Syariat Islam dan Kemaslahatan Manusia di Era New Normal Pada Kegiatan Keagamaan dan Pendidikan. Fenomena: Jurnal Penelitian, 12(1), 89-106.

Yanti, N. P. E. D., Nugraha, I. M. A. D. P., Wisnawa, G. A., Agustina, N. P. D., \& Diantari, N. P. A. (2020). Gambaran Pengetahuan Masyarakat tentang Covid-19 dan Perilaku Masyarakat di Masa Pandemi Covid-19. Jurnal Keperawatan Jiwa. 